\title{
A tale of two cities: A comparative study of media narratives of the battles for Aleppo and Mosul
}

Media, War \& Conflict

$1-30$

(C) The Author(s) 2019

(c) (i) (5)

Article reuse guidelines: sagepub.com/journals-permissions DOI: I0.1 I77/I7506352/9870224 journals.sagepub.com/home/mwc

\section{Johannes Scherling}

Karl-Franzens-University of Graz, Austria

\begin{abstract}
The battles for Aleppo (2012-2016) and Mosul (2016-2017) were two intense and brutal sieges, which resulted in 31,000 and 40,000 largely civilian casualties, respectively, as well as hundreds of thousands of refugees. Even though both campaigns were similar in many ways, they received an entirely different media echo. While Aleppo in its final phase was covered almost daily, detailing the suffering of civilians and the brutality of the Syrian government and its Russian allies, while ignoring actions of rebels, Mosul received much sparser treatment, mostly relating to atrocities committed by the Islamic State (backgrounding casualties inflicted by coalition forces). In both cases, the respective governments claimed to be fighting terrorists, but only in the case of Mosul was this narrative naturalized by the media. Drawing on various methods from critical media studies, this article analyses how and why the two battles were reported on differently by British mainstream media across the ideological spectrum. The purpose is to show how systemic bias based on a binary us vs them distinction leads to distortion and a reinforcement of dominant, populistic and partisan narratives that may threaten to background or ignore uncomfortable but important facts that would challenge people in power.
\end{abstract}

\section{Keywords}

Aleppo, critical media analysis, media, Mosul, thematic analysis, worthy/unworthy victims discourse

\section{Introduction}

The newspapers of today far too often rush into print with stories that are essentially little more than tips, or hints of something toxic or criminal. For lack of time, money, or skilled staff, we are besieged with 'he said, she said' stories in which the reporter is little more than a parrot.

\section{Corresponding author:}

Johannes Scherling, Department of English Studies, Karl-Franzens-University of Graz, Heinrichstraße 36/2,

Graz 8010, Austria.

Email: johannes.scherling@uni-graz.at 
I always thought it was a newspaper's mission to search out the truth and not merely to report on the dispute. (Hersh, 2018: 3-4)

In the world of modern media, in-depth reporting is a luxury, and frequently must take the back seat to breaking news first, and to constrictions of time and money. The above quote by veteran journalist Seymour Hersh illustrates that, through such practices, readers are left with reported opinions by the different sides at best.

In times of war, however, it is fact-based reporting that may turn the tide of public opinion for or against a conflict, or involvement in a conflict. Hersh himself became famous for exposing the My Lai massacre during the Vietnam War, and the pictures that he published dramatically changed public opinion on the war (see Jones, 2018; Shapira, 2018). One of the main problems of war reporting is accessibility, as only few reporters would dare to venture into the actual conflict area. This results in a dependence on second-hand sources, most of which are invested parties with an interest in a certain outcome of the conflict (see Cockburn, 2017a). The end result is therefore likely to be a report that is highly biased and adopts and/or naturalizes a perspective of one of the parties involved in the war, and will thus tend to evaluate similar war situations quite differently depending on whose side is heard, reported and represented.

Two very timely examples of such biased reporting were the battles for Aleppo in Syria (2012-2016) and for Mosul in Iraq (2016-2017), which were both characterized by extreme brutality on all sides and mass casualties among the civilian populations. A major difference, however, lay in the actors involved in the conflict: in one case, the West was fighting a terrorist group, in the other case, enemies of the West were fighting armed groups, many of which themselves constitute, or are linked to, terrorist groups. The reporting of the two events varied greatly. Aleppo became the first social media war, with dozens of messages and videos emerging from the rubble on a daily basis, which caused empathy with the victims' and rebels' perspective; Mosul, on the other hand, was a war that - similar to Iraq - used embedded journalism and thus adopted the perspective of those engaged in the offensive.

The following analysis aims to compare media coverage of Aleppo and Mosul in UK mainstream media in order to see to what extent similar happenings are described differently and how this is connected to the primary sources' vested interests.

\section{Media, frames and propaganda}

Media organizations, for pragmatic reasons, are highly reliant on official sources (Chomsky and Herman, 2002[1988]; Cook, 2005[1988]; Entman, 2004). Official sources are seen as authoritative and trustworthy, and are therefore preferably drawn on because the costs of verification are minimal as reliability is presupposed. This - alongside other filters such as ownership, advertising, flak and pro-market/anti-terrorism ideology results in mainstream media performing a propaganda function for government agendas, according to Chomsky and Herman (2002[1988]). Simply repeating and reinforcing government narratives, they state, effectively leads to a distinction of news stories - and particularly human elements in news stories - into those worthy and unworthy of 
reporting (pp. 31-35). This distinction depends in large part on whether these stories reflect profitably or poorly on the respective governments.

The reliance on official sources increases even more in times of war, where journalists' "'formal' autonomy is undermined by national security considerations that restrict the free movement of reporters in the battlefield and subject them to surveillance and harassment should they reveal "uncomfortable" truths about government activities' (Freedman, 2017: 72). As Bagdikian (2004: 86) maintains, 'Wars are particularly vulnerable to one-sided reporting because war and approaching war arouse patriotism and support of the country's armed forces.' Beside this, two other aspects need to be factored in: the difficulty of accessing the front lines, and the practice of embedded journalism and the limitations it entails.

The first factor - patriotism - is also commonly known as the 'rally-'round-the-flag' phenomenon (Murray, 2017) and means that, in times of crisis - real or perceived - people and the media have a natural tendency to rally around their leader(s) when the us vs them dichotomy is invoked. Patriotism is a powerful coercive force in that anyone who sways from the official line will be called 'unpatriotic' - a tendency that is perhaps strongest in the US (Bagdikian, 2004: 85). This may result in journalists uncritically repeating officially pushed narratives, as the following quote by the legendary US journalist Dan Rather illustrates:

What we are talking about here - whether one wants to recognize it or not, or call it by its proper name or not - is a form of self-censorship. It starts with a feeling of patriotism within oneself. It carries through with a certain knowledge that the country as a whole felt and continues to feel this surge of patriotism within themselves. And one finds oneself saying: 'I know the right question, but you know what? This is not exactly the right time to ask it . .' There was a time in South Africa when people would put flaming tyres around people's necks if they dissented and, in some ways, the fear is that you'll be necklaced here. You'll have a flaming tyre of lack of patriotism put around your neck. Now, it's that fear that keeps journalists from asking the toughest of tough questions. (BBC, 2002)

The second factor - access - derives from the difficulty of directly accessing a conflict situation which may require military permission (Philo, 2008) as well as the real danger of suffering physical harm or being taken as a hostage by one of the warring parties (RSF, 2018), as was the case in Syria, for example (BBC, 2018; Callimachi et al., 2019; The Guardian, 2019). This leads to a limited choice of getting 'on the ground' information, the easiest of which is to draw on official sources involved in the conflict. The third factor, embedded journalism, has become common practice since the first Gulf War (Bagdikian, 2004: 80). When being embedded, journalists join a military unit and are able to see the war through the soldiers' eyes. This also means, however, that they can only see what the military allows them to see and will only hear what the military tells them, both of which make it unlikely that different perspectives or human rights abuses of their military unit will be seen or receive coverage. It also guarantees a very unrepresentative perspective of a conflict situation which is then presented as though it were representative (Cockburn, 2010). These three factors illustrate the overwhelming - and often unquestioned - reliance on official sources, which frame a conflict through a very narrow lens. 
According to Freedman (2017: 73), because of this strong dependence on official sources 'one of the most common journalistic narratives has long been to "demonize" enemies as a means of justifying intervention.' This narrative is relayed through the adoption of official frames, which represent a conflict in such a way that intervention seems mandatory, even inevitable. Framing, therefore, is a decisive factor in how a story will be understood.

Entman (1993: 52) sees framing as the process of 'select[ing] some aspects of a perceived reality and mak[ing] them more salient in a communicating text, in such a way as to promote a particular problem definition, causal interpretation, moral evaluation, and/ or treatment recommendation for the item described'. De Vreese (2005: 53), similarly, defines a frame as 'an emphasis in salience of different aspects of a topic'. Thereby, an event such as 9/11 can be defined as an 'act of war' caused by 'envy' and 'ideology', the responsible actors being al-Qaeda and the Taliban, defined as 'evil', and the remedy is 'war' (Entman, 2004: 24-25). Important elements of framing are 'selection, emphasis and exclusion' (Gitlin, 1980: 7, quoted in De Vreese, 2005: 53), and hence framing analysis also stresses information that is left out of the frame precluding alternative approaches to solving an issue. In the example from $9 / 11$, for instance, the war framing makes it impossible to attempt a peaceful solution (such as international law enforcement), as this is not a meaningful response to a 'war' situation.

News frames are not static and merely textual, but involve contextual factors such as the addressor, the addressee and the cultural environment as well (Entman, 1993), and comprise three interdependent and consecutive factors: frame-building, frame-setting and framing effects (De Vreese, 2005). According to De Vreese (2005: 52), 'frames in the news may affect learning, interpretation, and evaluation of issues and events', and therefore have a direct effect on audience understanding (see De Vreese, 2009). As was shown, for example, in studies by the Glasgow University Media Group (e.g. MacLeod, 2018; Philo and Berry, 2011[2004]; Philo et al., 2013), the frames and explanations that news media use to portray an issue correlate very closely with the knowledge that the audience has on a particular topic. If that knowledge, hence, is based largely on official frames - and with them their problem definitions, causal interpretations and remedy suggestions - then this might lead to the audience 'falling in line' with the viewpoint that a government is pushing on issues of crucial importance.

\section{Background context}

The battles for Aleppo and Mosul share a number of important details. Not only did they take place at approximately the same time, but they also had similar casualty and damage figures, and were led with similar justifications - to fight terrorism. The ensuing subsections will be concerned with discussing the background stories for each offensive and in doing so will attempt to reflect each event from a variety of viewpoints.

\section{The battle for Aleppo}

The battle for Aleppo was a major confrontation between the Syrian government forces of President Bashar al-Assad and various forces opposed to the government, and it lasted from July 2012 to December 2016. In essence, however, Aleppo was used as a 
metonymical expression for eastern Aleppo, as the city had been divided into two parts since mid-2012 (see Barrington, 2016; BBC, 2016), when armed opposition forces captured parts of the city as well as its Old City, while the western - and, with a population of 1.5 million, more populated - part of the city remained under government control (see Shaheen, 2016). After several years of military impasse, and with the help of the Russian air force, the Syrian Army commenced what effectively became a siege of eastern Aleppo as of mid-July 2016, a siege that became airtight by October 2016, when the army started a large-scale offensive to retake the opposition-held areas (see Barrington, 2016; UNHCR, 2017). The parties involved in the fighting are often simplified into the dichotomy of Assad versus the rebels, but in fact, the situation is multipolar and complicated. According to Amnesty International (2015a: 10-12), the armed opposition is indeed very heterogeneous, and comprised more than 30 different groups (roughly organized into two coalitions: Aleppo Conquest and the Army of Conquest), most of which are clearly Islamist in character, some of which, such as Jabhat al-Nusra, have direct links to al-Qaeda and receive funding from various Gulf States. The latter, as also confirmed by US military officials, was the controlling force in eastern Aleppo (see Bertrand, 2016).

The battle for Aleppo resulted in the deaths of approximately 31,000 people during its four and a half years (see Violations Documentation Center in Syria, nd). A preliminary report by UNITAR based on satellite images from 18 September 2016, showed a total of approximately 4,773 structures destroyed in (western and eastern) Aleppo, largely by government airstrikes (see UNITAR, 2016), while an emergency mission by UNESCO showed that "some $60 \%$ of the old city of Aleppo has been severely damaged, with $30 \%$ totally destroyed" (UNESCO, 2017).

The parties involved in the fighting propagated various contradictory narratives. The armed opposition groups as well as activists operating in Aleppo and those supporting them portrayed the battle as an indiscriminate 'slaughter' of the innocent, and as an attempt to 'bomb innocent civilians into submission' (The White House, 2016c), in which government forces deliberately targeted women, children, doctors and rescue workers, as well as hospitals and schools (see Bertrand, 2016). In the UN, US Ambassador Samantha Fox compared the events in Aleppo to other massacres of recent history: 'Aleppo will join the ranks of those events in world history that define modern evil, that stain our conscience decades later. Halabja, Rwanda, Srebrenica, and, now, Aleppo' (Eshchenko and Sterling, 2016). In a joint statement by the leaders of Canada, France, Germany, Italy, the UK and the US on the situation in Aleppo, the leaders spoke of hospitals and schools 'appear[ing] to be targets of attack in an attempt to wear people down', condemning the Syrian government for the 'use of barrel bombs and chemical weapons' (GOV.UK, 2016; Walker, 2016). In terms of the armed opposition groups involved, a distinction is noticeable between socalled moderates - seen to represent the will of 'the people' for democratic change - and Islamist groups with links to al-Qaeda. This distinction is visible in the following wording by US Press Secretary Josh Earnest during a press briefing on 9 September 2016:

I think what we have seen is we have seen a willingness on the part of most opposition groups to abide by a Cessation of Hostilities when they're not provoked by the regime. And the reason for that is these opposition groups represent the people who are being slaughtered by the government. These opposition groups are the ones that are clamoring for a political transition inside Syria. (The White House, 2016a) 
The Syrian government and its allies - mostly Russia and Iran - saw the battle as one of 'liberating' the eastern part of the city from terrorist groups holding it hostage. Consequently, the groups are not referred to as 'rebels' or 'opposition', but rather as 'terrorists' and 'militants' (see RT, 2016c) The main focus of the narrative is the presence of groups with direct links to al-Qaeda and ISIS. Russian Foreign Minister Lavrov, for instance, was quoted in Russia Today on 3 December 2016 as saying that 'Al-Nusra . . . directs the militants in the unliberated parts of eastern Aleppo' (RT, 2016b). This serves as a justification for repeated ceasefire violations and continued bombings by forces supporting Assad as these Islamist elements use civilians as 'human shields' (Sabbagh, 2016). Other central claims against armed groups in eastern Aleppo include keeping civilians against their will, monopolizing food and selling it only to those sympathetic to them as well as suppressing protests under threat of imprisonment or worse (see RT, 2016a; Sabbagh, 2016; Kinzer, 2016).

The UN as well as human rights organizations have long been criticizing all parties involved, accusing them of human rights violations on a large scale. As early as 2015, Amnesty International published a report entitled "Torture was my punishment" Abductions, torture and summary killings under armed group rule in Aleppo and Idleb, Syria', accusing armed rebel groups of serious violations against human rights by submitting civilians to torture, disappearing them, as well as executing them without due process (see Amnesty International, 2015a: 4). In addition, these groups are accused of indiscriminate shelling of civilian areas in western Aleppo to terrorize the population there (see Oborne, 2016), in addition to choking any criticism of their rule through threats and censorship (pp. 15-17; OHCHR, 2017b: 15). The UN Office of the High Commissioner for Human Rights, in its report on Syria from February/March 2017, agree with this assessment noting that:

Some armed groups also committed the war crimes of withholding the distribution of humanitarian aid from the besieged population under their control, and actively denied civilians freedom of movement, used civilians as human shields, conducted arbitrary arrests and used civilian buildings for military purposes. (p. 20)

It also concluded that 'as the situation deteriorated in eastern Aleppo and people tried desperately to flee, some armed groups violently prevented them and used them as human shields' (p. 1). At the same time, both bodies acknowledge and condemn atrocities committed by Syrian government forces and their allies, accusing them of preventing aid from reaching the civilian population, targeting civilian infrastructure and humanitarian aid convoys, as well as submitting the people of eastern Aleppo to forced displacement, a violation of fundamental human rights (see Amnesty International, 2015b; OHCHR, 2016; OHCHR, 2017b).

\section{The battle for Mosul}

The battle for Mosul was a major campaign to oust ISIS's presence in the Iraqi city of Mosul, which had fallen to the armed group in the early summer of 2014 and from where Islamic State's leader al-Baghdadi had officially declared its caliphate from the Great Mosque of al-Nuri. Some Sunni citizens of Mosul are said to have welcomed ISIS because they had felt mistreated by the central Shia government in Baghdad (see 
Department of Defense, 2017). The setup of the conflict was less complex than Aleppo as there was only one armed group - ISIS - in control of the territory. The actual offensive to retake Mosul from ISIS began in October 2016, spearheaded by the Iraqi military and supported by US airstrikes, and was completed in July 2017, when Iraqi Prime Minister al-Abadi pronounced Mosul 'liberated' (see Sky News, nd). The fight to retake the city was accompanied by massive airstrikes and street fighting using imprecise weaponry on the one side, and by the use of civilians as human shields, summary executions and improvised explosive devices on the other, leading to immense civilian suffering (OHCHR, 2017a). The official civilian death count of the offensive is contested, but is generally agreed to be in the thousands. A Kurdish intelligence report, published by The Independent, puts the number as high as 40,000 (see Cockburn, 2017b), along with swathes of destroyed areas. UN Habitat counted 9,901 buildings that were either severely damaged or totally destroyed, 86 percent were residential buildings (see Rodgers et al., 2017; UN HABITAT, 2017; Adriaensens, 2017) At the same time, several hundreds of thousands of people were forcibly displaced through the fighting (see UNHCR, 2017).

The narrative propagated by the US-led coalition forces could be summarized as 'liberation' of Mosul from the hands of ISIS, the military forces engaged in the fighting being often referred to as 'counterterrorism forces' (see Garamone, 2016). Displacement of the population is acknowledged, but blamed on ISIS, as in this statement by former President Barack Obama:

If in fact we are successful, how do we deal with what could be a humanitarian crisis. Because ISIL, when it occupies these territories, it bleeds them dry. It feeds off them. It oppresses the local populations. It's not very good at governance. And so just basic functions like electricity and water start running low. People are fleeing from their homes. There will be significant displacement. (The White House, 2016b)

The narrative suggests that there is a unique causal relation between people fleeing and the ISIS regime, to the virtual exclusion of any other causalities. This viewpoint was repeated by US General Townsend, who stated in March 2017 that 'in my mind, all the responsibility for any civilian deaths, the moral responsibility for civilian deaths in Iraq and Syria belongs to ISIS' and that 'most [civilians] are dying at the hands of ISIS and that's the real horror' (Department of Defense, 2017). The narrative also stresses the difficulties of fighting in the narrow streets of Mosul as an implicit justification for civilian deaths caused.

Just recently in the last two weeks, we have hit the hard urban old-town core, old town Mosul where the streets and [sic] the narrowest and the construction is the most dense. It is there that the enemy has invested two and a half years of defensive preparations. It is there where the fighting has gotten extraordinarily brutal ... So I think that's really the explanation for the civilian casualties. The civilians are there. Some of them have been able to escape. Those that have not been able to escape are held against their will.

In total, the coalition narrative focuses on ISIS's brutality and sees any human rights violations committed by its forces as directly tied to, conditioned and necessitated by ISIS's actions. 
For NGOs, there was also a different side of the narrative. In its 2017 report 'At any cost - the civilian catastrophe in West Mosul, Iraq', Amnesty International criticizes all actors involved of serious violations of humanitarian law. While acknowledging that 'IS tactics and violations created particular challenges for pro-government forces in terms of civilian protection in west Mosul', anti-ISIS forces were also responsible for the enormous civilian casualties due to 'the use of unsuitable weapons or failure to take other necessary precautions', resulting in 'indiscriminate [and] disproportionate' attacks (p. 6). According to Airwars, a monitoring group tracking civilian casualties in Iraq and Syria, which is quoted in the report, 'between 19 February and 19 June 2017, attacks launched by Iraqi and coalition forces may have caused the deaths of as many as 5,805 civilians', adding that 'even this figure may be an underestimate, as it has been difficult for monitors to record deaths and injuries due to the intensity of fighting (p. 6). Human Rights Watch accused Iraqi forces of having 'summarily executed, tortured, and forcibly disappeared hundreds of ISIS suspects' in their battle against ISIS (Human Rights Watch, 2018). In addition, it maintains that

Iraqi and US-led coalition forces bombarded civilian objects including homes and hospitals in ISIS-held areas. They have fired inherently imprecise ground-fired munitions, including mortars, grad rockets and Improvised Rocket-Assisted Munitions (IRAM), into densely populated areas. In addition, aircraft have dropped explosive weapons with wide-area effects on these areas ... It is likely that Iraqi and coalition forces have killed many thousands of civilians in the course of their military operations against ISIS.

Another non-profit organization, the Geneva International Centre for Justice, presided over by Hans von Sponeck, former United Nations Assistant Secretary General and UN Humanitarian Coordinator for Iraq, agrees with this assessment, referring to

a statement to state television, published on 11 July 2017, [in which] a member of the Iraqi parliament, Hakim al-Zamili, head of the parliament's security and defence committee, said that Iraqi forces had killed about 28,000 'ISIS' members during the liberation battles and military operations in Iraq. However, taking into account that most estimates of ISIS members in Iraq amount to no more than 7,000 members gives us no doubt that of the people killed many were civilians. (Geneva International Centre for Justice, 2017)

The organization additionally criticizes the 'total destruction of Mosul' through which 'hundreds of archaeological sites . . . were destroyed by the Coalition and Iraqi forces', in addition to 'the destruction of the city's infrastructure such as roads, bridges, water and sewage systems, and communication facilities' through indiscriminate airstrikes.

\section{Data corpus and methodology}

\section{Corpus}

For the analysis of UK media discourse on these two military campaigns, the following four British newspapers were used as a data source: The Guardian (liberal) and The Daily Telegraph (conservative) as representatives of broadsheets, as well as The Daily 
Mirror (liberal) and The Daily Mail (conservative) as representatives of tabloid papers. The choice of newspapers was based on a consideration of representativeness of liberal and conservative viewpoints as well as circulation figures. All four newspapers are ones with the highest circulation figures that are not behind a paywall. News articles were acquired using the search engine LexisNexis.

For the battle for Aleppo, the corpus consists of 71 news articles, spanning from 1 November 2016 until 22 December 2016, when the campaign officially ended with the retaking of the city. For Mosul, 49 news articles were used, from the time frame of 16 October 2016 until 9 July 2017, when Mosul was declared liberated. Only news articles were used, opinion articles were excluded, as they explicitly state the author's opinion, while the news articles are supposed to present the 'facts' without explicit evaluation by the author. Some articles also included largely similar elements; such 'duplicates' were also excluded. Generally, the lower number of articles dealing with Mosul despite the longer time frame of the campaign seems to reflect a lower - or rather, more eventfocused and selective - media interest in comparison to Aleppo.

\section{Methodology}

This analysis uses a hybrid methodology composed of various linguistic and media studies approaches. As a basis, it adopts a modified version of the Glasgow University Media Group's Thematic Analysis (see Philo, 2004; 2008; Philo and Berry, 2011[2004]; Philo et al., 2013). This method from media studies aims to identify explanatory frameworks in news discourse that explicitly or implicitly indicate causality and responsibility, while also attempting to identify which perspectives dominate in the discourse on certain economic and/or political conflicts. Perspectives are often encoded in lexical choices as well, which is why I will also be analysing what is called the text population (see Goatly, 2000; Talbot, 1992), i.e. the way in which the actors, their actions and the event are described in terms of noun phrases (heads and modifiers).

A second focus will be on the use of sources in news reports. By adopting a particular source, a journalist makes an important choice - giving someone the power to frame a news story as well as lending the source a certain amount of legitimacy, especially if the account remains unchallenged. In war reporting, two sources are prominent: official or government sources on the one hand, and eyewitness reports on the other. As outlined above, the general tendency to favour official sources is often the result of a pragmatic choice. According to Timothy Cook (2005[1998]: 91-92):

[Journalists] . . have to be concerned with who or what is authoritative enough to appear on the news, since the credibility of those sources will rub off on the overall report. Consequently, reporters constantly gravitate towards 'persons in a position to know,' whereby they may then defend themselves from potential criticism against giving airtime or print space to someone who did not deserve it.

By adopting such official narratives, the worldviews, causalities, responsibilities and treatment suggestions are often adopted alongside the overall narrative framework, which is particularly important in times of conflict, when the choice of treatment has an 
immediate effect on the wellbeing of entire populations. The ubiquity and impact of such causality and responsibility frames has been extensively ascertained in a number of studies in framing analysis (e.g. Boukes et al., 2015; Hannah and Cafferty, 2006; Iyengar, 1991, 1996; Kim et al., 2010; Semetko and Valkenburg, 2000).

Eyewitnesses are important sources because they allow the audience to see the conflict through the eyes of those affected, and therefore carry great authentic weight due to their seemingly unmediated nature. However, eyewitness reports are notorious for being very unreliable (see Cru, 1988), simply because human memory is unreliable. Additionally, as Walter Lippmann (2012[1920]: 42) points out,

The number of eye-witnesses capable of honest statement is inadequate and accidental. Yet the reporter making up his news is dependent upon the eye-witnesses. They may be actors in the event. Then they can hardly be expected to have perspective. Who, for example, if he put aside his own likes and dislikes, would trust a Bolshevik's account of what exists in Soviet Russia or an exiled Russian prince's story of what exists in Siberia? Sitting just across the frontier, say in Stockholm, how is a reporter to write dependable news when his witnesses consist of emigres or Bolshevist agents?

Essentially, it is impossible to ascertain whether the eyewitnesses' memories are accurate or whether they are themselves personally invested in an event or free to express their opinions in a conflict zone. Nevertheless, they are drawn on frequently in news discourse on wars, at least when the aggressor in the war is a group or state that is not allied/inimical to the country the medium is based in.

The choice of official sources versus eyewitness reports has a tangible effect on descriptive quality. Eyewitnesses let the reader empathize with the suffering of people; they provide context to an otherwise abstract conflict and align the readers with the victims' perspective. Official sources, on the other hand, when they are themselves actors in the conflict, have the effect of diverting attention away from human suffering towards justifications and technicalities; victims then become mere numbers. The choice of source, and the intensity with which they are employed, consequently leads to what Chomsky and Hermann (2002[1988]) have called the distinction into worthy and unworthy victims, with worthy victims being duly acknowledged, contextualized and humanized, while unworthy victims receive scant coverage without any context that might activate reader emotions.

In the following analysis, all of these aspects will be taken into account, attempting an answer to the following research questions:

RQ1: Which explanatory frameworks are drawn upon from which sources to describe the battles of Aleppo and Mosul?

RQ2: How do these frameworks relate to the portrayal of agency and victims in these battles?

RQ3: What is the relationship between the framing of each conflict and the overall evaluation of the event? 


\section{Analysis}

The battle for Aleppo and the battle for Mosul are comparable on a number of issues. In both cases, a city, or part of a city, was captured by outside Islamist groups which did not use to have a base in that city. In both cases, the offensive to retake the city was called a mission of liberation. In both cases, the group or groups holding the city were labelled terrorists. And in both cases, heavy ordnance and bombing raids were used in addition to regular ground forces, leading to immense destruction and a horrific death toll. Nevertheless, the news framings of Aleppo and Mosul show some remarkable differences (see also Cromwell and Edwards, 2017).

The analysis will be conducted by focusing on four variables, which are derived from the media-theoretical background outlined above, and which directly affect the framing of an event: (1) coverage of victims and perpetrators (i.e. are victims treated similarly irrespective of who perpetrates the attack?); (2) the use of sources (i.e. are they treated as trustworthy?); (3) agency (i.e. is agency similarly highlighted in any attack); as well as (4) evaluation (i.e. how do journalists evaluate the events for the reader?).

\section{Coverage of victims and perpetrators}

One major qualitative difference in the reporting of the two events is how the victims are treated. The suffering of the people in eastern Aleppo was visceral, described in great detail, with many eyewitness reports used to illustrate the horrific details of everyday life under siege.

(1) Jet fighters pounded rebel-held east Aleppo through the night and into Wednesday morning, continuing the opening salvo of a long-awaited campaign that Bashar al-Assad and his Russian allies hope will crush the opposition in Syria's former industrial capital ... Doctors said an ambulance driver had been killed in the airstrikes, and many were under the rubble, after a bombardment which included 'barrel bombs', largely inaccurate cylinders packed with explosives dropped from helicopters and usually targeting civilian areas. Residents sent audio messages with sounds of intense bombardment and shelling. 'Horror is back to Aleppo', said Abdulkafi al-Hamdo, a teacher in the city in a text message. (The Guardian, 16 November 2016)

As the extract above shows, there is great detail awarded to the government's actions, which are framed as an attempt to 'crush the opposition', thus adopting the rebel narrative rather than the Syrian government's narrative of 'fighting terrorism'.

(2) One girl, 10-year-old Hiba, is among 47 children in the Al Momayzon orphanage after bombs killed her entire family. Her greatest fear is that she too may end up dying in the rubble. But as bombs fall like rain, Hiba does not want to flee. Instead she dreams of becoming an architect so she can rebuild the city, where the relentless aerial bombardment by forces of President Bashar al-Assad and Russia's Vladimir Putin [sic]. (Daily Mirror, 27 November 2016) 
The above sample shows one of numerous instances where the life of an individual inside eastern Aleppo is contextualized in great and emotional detail, including the dreams that this girl embraces even while being bombed. Besides these examples, we also find entire articles concerned with witness accounts that allow readers to immerse themselves in their suffering. This is a clear example of Herman Chomsky's notion of the worthy victim, which everyone can empathize with due to very detailed and emotional coverage.

Witness reports in the case of Mosul are much sparser and lack the details found in Aleppo. Where they appear, they are mostly concerned with witness accounts of ISIS victims, rather than with victims of coalition bombing. Where coalition bombing victims are given a voice, this is usually mitigated in various ways.

(3) Thousands have been killed or wounded - murdered by the jihadis, blown up in air-raids by the US-led anti-Isis coalition, or killed after being caught in street fighting. (The Guardian, 9 July 2017)

(4) Mosul's civilians'] predicament has been highlighted in the aftermath of coalition airstrikes that demolished an area of Mosul Jdeideh neighbourhood last week, killing at least 150 people and leading to claims that neither US commanders, nor the Iraqi officers who called in the strikes, have been paying sufficient regard to civilians caught up in the war. (The Guardian, 31 March 2017)

(5) Iraqi and US forces have previously stated that Isis deliberately blended among the civilian population and, in some cases, had stationed themselves near civilian targets in a bid to increase casualties and to slow the offensive against them. The Centcom statement said, 'Our goal has always been for zero civilian casualties .. . Isis's inhuman tactics of terrorizing civilians, using human shields, and fighting from protected sites such as schools, hospitals, religious sites and civilian neigborhoods. (The Guardian, 25 March 2017)

(6) The Syrian Observatory for Human Rights monitoring group said that 33 people were killed in the Mansura bombing and 49 in Al-Jineh, where the US target was a meeting of Al-Qaeda officials. (The Guardian, 28 March 2017)

Generally, there is a tendency for summarily reporting civilian casualties in terms of numbers (e.g. [4] and [6]), rather than zooming in on the individuals. This has the effect that readers will not be equally able to empathize with the victims as they are 'just numbers'. Additionally, when casualties are reported, they are regularly attributed to several different factions and factors, such as ISIS, coalition airstrikes, street-fighting or booby traps (e.g. [3] and [4]). There is rarely a clear attribution of guilt when coalition airstrikes are involved. When there is, however, the killing is not so much discussed as 'brutal', 'indiscriminate' or 'deliberate', as was the case in Aleppo, but rather as a result of negligence (see [4]).

When civilians who suffered from coalition strikes are interviewed, there is a tendency to mitigate the coalition's responsibility by adding official statements that the area was a 'battlezone' at the same time as emphasizing that the coalition should have used more appropriate weapons. This is quite different from the way bombings by government and Russian forces are described in Aleppo, where witness reports helped 


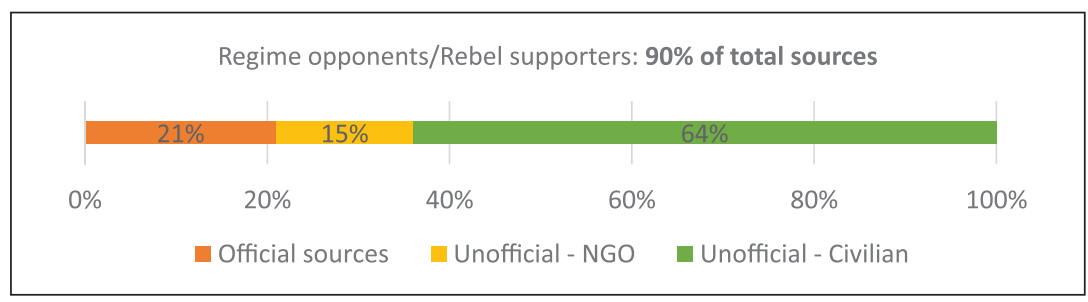

Figure I. Use of sources - Aleppo.

to show the extent of brutality and destruction rather than producing excuses for the perpetrators. In yet other cases, the victims are described as collateral damage of attacking legitimate targets, such as in the last example, where the claim by US authorities that they had targeted an al Qaeda meeting, is adopted and reported as fact (see [6]), while similar claims by Syrian officials that they were targeting 'terrorists' are immediately cast into doubt.

\section{Use of sources}

In the case of Aleppo, there is heavy use of unofficial sources (see Figure 1), of eyewitnesses on the ground, of doctors, helpers, rebel spokespersons - often summarily called 'activists' - who narrate and comment in great detail on their experience under regime bombardment.

A point that has been raised regarding reporting from out of eastern Aleppo that warrants further consideration is the quality of free expression within the besieged city. One of the violations by non-state armed groups in eastern Aleppo criticized by Amnesty International in a 2015 report concerned the abduction and detention of journalists and media activists in rebel-held territory, 'solely for expressing their opinion through social media and local newspapers, in particular for criticizing the rule of the armed group in question and reporting on issues that are deemed politically and socially unacceptable' (Amnesty International, 2015a: 16) In this regard, journalist Patrick Cockburn adds:

Since at least 2013 it has been too dangerous for journalists to visit rebel-held areas because of well-founded fears that they will be kidnapped and held to ransom or murdered . . .

In areas controlled by people so dangerous no foreign journalist dares to set foot among them, it has never been plausible that unaffiliated local citizens would be allowed to report freely.

In East Aleppo any reporting had to be done under licence from one of the Salafi-jihadi groups which dominated the armed opposition and controlled the area - including Jabhat al-Nusra, formerly known as the Syrian branch of al-Qaida. (p. 7)

Cockburn adds that this 'doesn't necessarily mean that the reports in the press about the devastating effects of shelling and bombing were untrue', but they were 'selective'. 
Considering this, it would at least have seemed appropriate to treat such witness accounts with a little more critical distance, and to point out the potential biases of sources in such a dangerous surrounding. In addition to individual activists, the most dominant source on the entire Syrian conflict is the London-based Syrian Observatory for Human Rights (SOHR), which is frequently drawn on for casualty reports. Issues that may cast doubt on whether its claims are trustworthy are twofold: one is that it is itself an invested party in the conflict as it is supportive of the rebel forces; two is that, while its name suggests a considerable organization with a headquarters, it is, in essence, a one-man organization that draws on a network of sources on the ground in Syria (see MacFarquhar, 2013; Anderson, 2015). These sources are again invested parties, namely activists, supporting the opposition. So, for all its worth of providing on-the-ground information, its ideological leaning hardly makes it a neutral source, a fact that is frequently omitted when they are cited, being only referred to as 'The Syrian Observatory for Human Rights, a war monitor'. Another notable source that UK media can be seen to draw on are 'spokespersons' for some of the rebel groups, such as Noureddine al-Zinki or Ahrar al-Sham, both of which are Islamic fundamentalist groups with links to terrorist organizations such as the al-Qaeda affiliate al-Nusra (Amnesty International, 2015a: 10-11). Their eyewitness reports, too, are taken at face value.

Official sources such as Russian or Syrian officials rarely feature, and when they do, their statements are usually limited to statements on the status of the military operation. What is conspicuous is that civilians who have fled eastern Aleppo towards government-held western Aleppo are given no voice at all, but the reports seem to assume that they fled from the bombs, rather than from the armed opposition groups. This is notable as there were large numbers of people fleeing to western Aleppo in the course of the offensive, so interviewing them might have given the audience an insight into what they experienced within the besieged area. However, when mentioning such refugees, the newspapers analysed prefer to imply they were fleeing from airstrikes, as in this example:

There were up to 250,000 civilians - 100,000 of them children - trapped in east Aleppo when it came under siege. Many of them fled into government-held west Aleppo last week as airstrikes intensified, but there are still thought to be tens of thousands awaiting evacuation. (The Guardian, 15 December 2016)

Here, the phrase 'as airstrikes intensified' creates an implicit causality between the people's flight and the government's airstrikes and leaves armed groups' oppression out of the equation. Considering that, when the evacuation of Aleppo finally happened, a vast majority of people voted to move to government-held western Aleppo $(\sim 50,000)$ rather than to rebel-held Idlib $(\sim 10,000)$, hearing those voices who fled from the rebels might have added an underrepresented aspect to the narrative (Irish, 2016).

In reporting Mosul, the use of sources is a rather different one, and appears more reminiscent of the embedded journalism of the Iraq War 2003.

There is a heavy use of official sources (see Figure 2) - both military and governmental - that are allowed to comment on the events and to explain and justify civilian casualties, as the following example illustrates: 


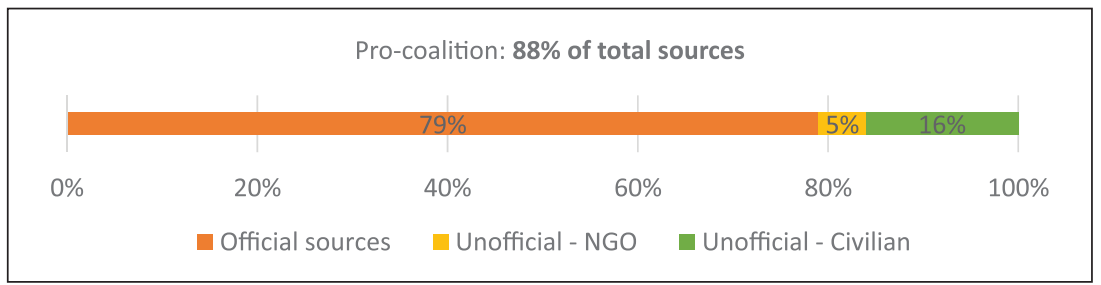

Figure 2. Use of sources - Mosul.

(7) The Pentagon has admitted that airstrikes it carried out on a house in western Mosul killed at least 105 civilians in one of the deadliest attacks anywhere in Iraq since the 2003 invasion to oust Saddam Hussein . . .

Four more civilians sheltering in another home were killed by debris from the blast. US Central Command said it did not know civilians had taken shelter in the home.

US officials say they went through close to 700 hours of footage taken from jets during, before and after the attack and sent investigators to the scene in the aftermath. The investigation compared explosive residue from the type of bomb dropped by the fighter jet with residue found at the scene.

'Post-blast analysis detected residues common to explosives used by Isis, but not consistent with the explosive content of a GBU-38 munition,' US Central Command said in a statement. (The Guardian, 25 May 2017)

There are numerous lines reserved for such official statements that align the reader with the perspective of the US-led coalition and the Iraqi fighters on the ground, whose claims remain unchallenged. Besides such officials, some civilians are also interviewed, mostly some that fled from ISIS into eastern Mosul.

(8) The children at Hamman al-Alil camp, aged between 10 and 15, shared stories of the horrors they had witnessed: family members killed in front of them, seeing dead bodies, and blood in the streets. Others spoke of seeing relatives shot by snipers or blown up by landmines, and of their homes being bombed.

Many spoke of the constant threat of Isis punishment, with death or imprisonment facing those who flouted the militants' rules.

One 13-year-old boy, Jad, told researchers: 'If we were caught in the street at the time of prayer, we might get lashed. Also, they used to perform beheading or whipping in the street every now and then . . . they used to hang the dead bodies on iron sticks in the streets for days.' (The Guardian, 5 July 2017)

The effect of statements by refugees from ISIS-held territory is to show the brutality of the jihadist group and the desperation of the civilians affected by them. Hence, ultimately, what the choice of these sources does is to create a particular responsibility frame that lends authority and justification to the military actions of the coalition and to offer reasons why the fight against ISIS claimed so many civilian lives. 
Conspicuously, what is very much absent are voices by civilians who were in some way victims of coalition airstrikes or street fighting. When they do occasionally feature, their criticism is mostly directed at military strategies rather than being a substantial critique of the operation. Sometimes, coalition soldiers are implicitly portrayed as the actual victims because of the difficulty of the operation, as in the following:

'I have never seen such hard fighting like this one, not because they have good fighters here . . but here it's maddening to fight amongst the civilians', said [Lt.Col.] Muntadher. 'Our soldiers have to be very careful. We can't just bomb a neighbourhood and then go clear it, we have to fight from house to house and that is costing us men.' (The Guardian, 1 February 2017)

The reader therefore gets the impression that the offensive itself is important and justified, and that in the heat of battle, wrong choices are made that negatively affect civilians. Ultimately, however, this is also shown to be ISIS's fault due to their brutal strategy of putting civilians in the line of fire.

\section{Agency}

Both the offensive in Aleppo as well as the one in Mosul resulted in considerably high civilian casualties and widespread destruction of infrastructure. However, these were reported notably differently for each event.

The killing and destruction in eastern Aleppo are frequently and repeatedly linked to airstrikes by the Syrian government and its Russian allies, while implying that this is a deliberate strategy (see [9]-[11]). The articles draw a clear connection, and use active sentence structures, to describe the ongoing events and the aftermath of bombings as well as of ground offensives (see [11]-[12]).

(9) The horror faced by 100 children trapped by Syrian government bombs raining down was brought home by a stream of 'final tweets' from people fearing they were about to die. (Daily Mirror, 14 December 2016)

(10) Doctors and nurses who chose to stay on in rebel-held Aleppo, working in hospitals regularly hit by bombing raids, now fear being jailed, tortured or killed for their commitment to saving lives. (The Guardian, 13 December 2016)

(11) Women and children are being rounded up and shot by militias loyal to Syria's brutal dictator, President Bashar al-Assad. Others are burnt alive as Syrian and Russian planes pulverize the city with cluster bombs and missiles. (Daily Mail, 15 December 2016)

(12) The atrocities being committed on the ground in Aleppo by Iranian proxies fighting alongside the Syrian regime, and from the skies by Russian planes, as horrifying as they are, should come as no surprise. Aleppo has been under siege for many months; its population has been brutally and indiscriminately attacked into submission and the scorched-earth policy adopted by the Assad regime, Russia and Iran comes as the international community has been focusing its attention on the US elections and the ongoing war with Isis. (The Guardian, 15 December 2016) 
In fact, the clear attribution of agency is so prevalent that the implied conclusion is that all deaths in Aleppo are on account of the Syrian regime and its allies. The fact that western Aleppo was also subjected to constant mortar fire and shelling by armed groups in eastern Aleppo easily escapes readers' notice. On rare occasions, this is mentioned, as in the Daily Mail on 5 November 2016:

(13) For the past fortnight, regime-held western Aleppo has been peppered by mortar and rockets, mainly fired by opposition fighters massed in the countryside to the west. They are trying, once again, to break the encirclement of the siege from the outside. Around 100 civilians have died as a result, with many times that number wounded.

The authorities here say 11,000 civilians have been killed in western Aleppo since the war began a third of them children. United Nations special envoy for Syria Staffan de Mistura said he was appalled and shocked by the high number of rockets indiscriminately launched on civilian suburbs of government-held Aleppo.

Most of the time, however, victims of rebel attacks are only mentioned in passing, their fates compared in quantity - and thus belittled - to those of the people in eastern Aleppo: 'Mortars and rockets have fallen on their areas [in western Aleppo] though nothing like the destruction and death of the regime airstrikes or barrel bombs on the other side' (Daily Mail, 4 November 2016).

In reporting the casualties in Mosul, newspapers use a different tone. While the loss of lives is bemoaned and civilian suffering decried, agency is less explicitly assigned to those responsible, except in cases when that agency can be traced to ISIS fighters.

(14) Mosul's residents have paid a steep price. Thousands have been killed or wounded - murdered by the jihadis, blown up in air raids by the US-led anti-Isis coalition or killed after being caught in street fighting.

The jihadis' many atrocities in Mosul and elsewhere brought them global infamy. About 1 million city residents are now displaced, many among them ill or malnourished. Reconstruction will be a major challenge. (The Guardian, 9 July 2017)

(15) Hundreds of civilians fled Mosul last month, as the fight against Isis reached a tipping point. More than 860,000 people have escaped into the liberated eastern part of Mosul since the war to recapture the city from Isis militants began last October. (The Guardian, 5 July 2017)

(16) The human toll of the war for Mosul continued to emerge from the ruins of the city on Thursday, as Iraqi troops escorted haggard families from narrow lanes near the ruined mosque . . . Earlier this week, hundreds of civilians streamed past destroyed buildings and into Iraqi controlled territory. (The Guardian, 22 June 2017)

As these examples show, killings, displacement and destruction are discussed in the passive voice ('have been killed'; 'are now displaced', 'destroyed buildings') or by 
presupposition ('reconstruction', presupposing destruction), hence not necessitating agency. When it is provided, this is done in the form of an enumeration of various factors accounting for what happened - ISIS, coalition airstrikes and street fighting - thus blurring agency. In the case of displacement of civilians, it is implied that this is entirely the doing of ISIS, rather than airstrikes also contributing to people fleeing the city (as was done in the case of Aleppo). In an example from the Daily Telegraph, civilians are said to 'have been caught in the crossfire, some in coalition airstrikes', which indicates that these were unfortunate accidents, rather than, for example, a conscious acquiescence of civilian casualties. On the other hand, 'the rest [of the civilians died] at the hands of Isil, which has been using the population as human shields', where clear intent and agency is discernible.

\section{Evaluation}

Evaluation refers to how the actors as well as the event are described and evaluated. For Aleppo, the armed groups in eastern Aleppo are referred to monolithically as 'opposition', thus backgrounding the many different groups working to overthrow the Syrian government.

(17) About 4,000 rebel fighters and civilians left the city on Thursday, the last group remaining in the shrunken patch of territory still nominally held by the opposition in the city. (The Guardian, 22 December 2016)

(18) It was also the last major urban stronghold held by rebels, and their defeat in Aleppo essentially recasts the opposition as a rural insurgency. (The Guardian, 21 December 2016)

(19) Activists trapped in the opposition's last sliver of territory in the city said progovernment forces had fired dozens of rockets from mid-morning. (Daily Mirror, 15 December 2016)

(20) [Aleppo's] loss would be a major blow to the opposition, which will be bereft of any major urban stronghold. (The Guardian, 12 December 2016)

(21) On Wednesday they seemed to melt away as loyalist fighters captured the Old City, which had been the frontline between the two sides and the nerve centre of the opposition. (The Guardian, 9 December 2016)

By referring to the armed groups summarily as 'opposition' or 'rebels', the impression is created that we are dealing with a homogeneous group of people united by a common purpose and a common vision. In fact, however, the Syrian 'opposition' functions as an umbrella term for a large number of different factions, some at war with each other and with different, contradicting goals. In December 2013, the BBC calculated that the opposition consisted of up to 1,000 armed groups (BBC, 2013), many of which joined forces into larger factions, and many of which were at war with one another.

Another effect of calling the armed groups 'opposition' is to evoke the democracy frame, especially when contrasted with the government. This implies that the opposition parties are legitimate political entities whose goal is a democratic Syria. This is in stark contrast to the fact that most of the groups have roots in Islamic fundamentalism and call 
for Sharia law (see Hauch, 2016; Sly and Ignatius, 2013). In addition to the discursive construction of the opposition as a homogeneous group, news discourse also makes no distinction between armed groups and the civilians under their control. Civilians remaining in eastern Aleppo are, almost by association, assumed to be aligned with and supportive of the armed groups as well as sharing their goals.

(22) The last fighters and civilians who were holding out in Aleppo are finally trickling towards the Turkish border. (The Guardian, 15 December 2016)

(23) There are only a few thousand left in the last remaining sliver of opposition Aleppo after more than 25,000 were bussed out to the relative safety of rebelheld countryside in recent days. (The Guardian, 21 December 2016)

(24) $[\mathrm{N}] \mathrm{o}$ one in his neighbourhood . . could leave and few would dare take an exit route to the regime-held west of the city even if they could. (The Guardian, 28 November 2016)

(25) Under the deal, civilians from east Aleppo would have been moved to Idlib at the same time as loyalists were shifted from al-Foua and Kefraya, two villages besieged by rebels, into government-held territory. (Daily Telegraph, 19 December 2016)

(26) Plans to evacuate the last remaining rebels and civilians from their devastated enclave in eastern Aleppo stalled yesterday, after fresh fighting put a negotiated truce in peril. (Daily Telegraph, 15 December 2016)

This is suggested by the use of coordinating conjunctions ('the last fighters and civilians', 'the last remaining rebels and civilians'), thus implying that they share common goals. Another method is to use generic references by referring to the entire group, rather than a part of that group. For example, the part of the sentence 'civilians from east Aleppo would have been moved to Idlib' suggests that all civilians in that part of the city would have been transferred but, in fact, it was only the rebel fighters and their families and sympathizers, while the rest fled to the government-held West (New York Post, 2016). Similarly, sentences such as (24) clearly side the civilians in eastern Aleppo with the armed opposition as well as implying that even those who flee to government-held areas do not do so because they want to.

The cause that the armed groups are fighting for is termed a 'rebellion' or 'revolution', both honorable causes with neutral or positive connotations, as both draw on the image of an unjust government and its purpose is to eliminate this injustice. Alternatively, the event could have been referred to as an 'armed uprising', potentially contradicting the Arab Spring frame (with its connotations of peaceful, democratic change) that was initially applied also to the Syrian conflict.

(27) Refusing to give up on a revolution they have been fighting more than four years for, they have said they will stay until the 'last drop of blood'. (Daily Telegraph, 9 December 2016)

(28) The city is central to the fate of the conflict. It is seen as a weathervane of the Syrian revolution because of its symbolic and strategic importance. (Daily Telegraph, 9 December 2016) 
(29) 'Terrorists' is the label attached to the opposition to Assad ever since the outbreak of the 2011 street uprising against his dictatorship - a revolution that morphed into a full-on civil war after the Damascus government decided to deploy military power, including missiles, barrel bombs and chemical weapons, against its own population. (The Guardian, 30 November 2016)

(30) Its [Aleppo's] fate has long been seen as a bellwether for the momentum of the Syrian war, and forces loyal to Assad hope to deal a fatal blow to the rebellion by seizing the last major urban stronghold under opposition control. (The Guardian, 22 November 2016)

These examples show the positive, hopeful connotations that are attributed to rebel activities. This is in stark contrast to the way that government operations to retake the city are described, which is called 'devastating', 'brutal', 'relentless', 'sickening' and a 'calamity', a 'siege', an 'onslaught', an 'affront to humanity'.

(31) As the world has watched the people of Aleppo die in their thousands, with no sign of UN humanitarian convoys reaching those in need even during brief 'humanitarian pauses' in the onslaught, various ideas have been put forward in western capitals on whether it was possible to shame Damascus and Moscow into letting aid convoys through. (The Guardian, 4 December 2016)

(32) Meanwhile, rebel fighters in rural areas continued to try to break the regime siege and open up a supply line to the opposition-held eastern side, which has been cut off since the summer. (Daily Telegraph, 5 November 2016)

(33) President Bashar al-Assad's forces, supported on the ground by Russian, Iranian and Lebanese Hizbollah fighters, have regained nearly two-thirds of the east in a blitzkrieg assault. (Daily Telegraph, 6 December 2016)

The lexemes used to refer to government operations are characterized by very negative connotations and associations of relentless violence. At times, intertextual references are employed, more or less explicitly linking government offensives to military tactics first employed by Nazi Germany ('Blitzkrieg'). The overall picture, therefore, is that rebel actions are seen as desperate attempts to survive and bring about positive change for Syria, while the actions taken by Syrian forces and the Syrian government are portrayed as brutal acts of indiscriminate violence with the intention to root out any lingering democratic aspirations.

The actors on the government side are described as 'loyalists', 'militias', 'proxies', 'fighters' or 'regime forces', where the term 'regime' implies a lack of (democratic) legitimacy as well as a degree of authoritarianism and thus delegitimizes the armed forces along with the government, because if the government is illegitimate, then so by extension are the forces that have sworn loyalty to this government. The terms 'proxies' and 'militias' are equally negatively connoted. While 'proxy' suggests the Iranians are doing something that Assad himself ought to be doing, 'militias' has clear connotations of illegitimate armies by non-state actors. The term 'loyalists' used for the Syrian Army appears to suggest that the issue is one of (freely chosen) loyalty to a person or 
government, rather than of a regular army using (forced) conscription and thus also delegitimizes the army as a state institution.

In the case of Mosul, the media outlets analysed uniformly refer to the 'liberation' and 'liberated parts' of the city, meaning that the retaking of the city is framed as something to be desired and something that will be an improvement to the status quo. It is referred to as an 'offensive', a 'long-anticipated battle', a 'fight to free Mosul'. The actors here are a 'coalition of forces', 'counterterrorism forces', 'elite international forces' or 'military forces', and hence have much more positive connotations than in the case of Aleppo. In Aleppo, the end result is characterized as a 'fall', all parts retaken by the government as 'fallen' (e.g. 'four different neighbourhoods of east Aleppo that had fallen under government control'). This implies a negative change following the basic conceptual metaphor of BAD IS DOWN. Additionally, when a city 'falls' to an army, it is usually assumed that this army is not supposed to be controlling the city, or that, at least, it is nothing desirable. The implications are that the armed groups are the rightful rulers of eastern Aleppo, and that the Syrian Army taking control will mean a change for the worse. The perspective that is encoded in these terms is quite apparent. While, in Mosul, the media take the perspective of the attacking force, in Aleppo, the perspective of the armed groups inside the city is adopted.

Finally, while Western involvement in Mosul is generally seen as positive, one of the reasons for the 'meltdown of humanity' in Aleppo is seen in a lack of Western involvement, and this works as one of the underpinning explanatory themes.

(34) For the US and the EU, the fall of Aleppo, Assad's survival and Russia's and Iran's ascendancy represent a generational foreign policy setback. Samantha power's attack [in the UN] reflected Washington's impotent rage. American influence in the Middle East is now at a very low ebb, at the very moment when the region is at its most chaotic. (The Guardian, 16 December 2016)

(35) The tragedy of Aleppo did not come out of a vacuum, it was created by a vacuum, a vacuum of Western leadership, of American leadership, of British leadership. (Daily Mail, 14 December 2016)

(36) Mr Osborne said the decision not to intervene in Syria had created a refugee crisis which had 'transformed the politics of Europe' and allowed a terrorist state to emerge 'in the form of Isis'. (Daily Telegraph, 14 December 2016)

(37) The result [of the Iraq invasion] is that most American and British politicians say never again. So does public opinion. Never again will our young men be sent into battle to topple a Middle-Eastern tyrant and try to establish democratic government in the name of decency. (Daily Mail, 15 December 2016)

All newspaper articles analysed here show a strong tendency to see the West as being not involved, as mere bystanders who watch the slaughter from afar. At the same time, they suggest that western intervention in the form of military action would be desirable and beneficent because it is done 'in the name of decency'. This desirability is also implied in (34), which suggests that there is a direct correlation between lack of American influence and the chaos in the Middle East. As a consequence, all the horrors taking place in Syria as well as the rise of fundamentalist elements in opposition to Assad is attributed 
to a 'lack of Western leadership'. Interestingly enough, such arguments entirely ignore what John Kerry, Secretary of State during the Obama administration, said on tape when talking to members of the Syrian opposition:

The reason Russia came in is because ISIL was getting stronger . . And we know that this was growing. We were watching. We saw that Daesh was growing in strength, and we thought Assad was threatened. We thought, however, we could probably manage, that Assad would then negotiate. Instead of negotiating, he got Putin to support him. (Weiss, 2017)

Additionally, it is of interest to note that Western action is seen as the only way forward to create peace and stability, as can be seen in the media reporting on Mosul, and the calls for intervention in Syria. However, when looking at the original roots of the chaos in the region to begin with, increasingly, the consensus is that such chaos would not have erupted had the US and Britain not invaded Iraq in 2003. One former advisor of General David Petraeus and Secretary of State Condoleeza Rice, David Kilcullen, even insists that 'there would be no Isis if we had not invaded Iraq' (Dearden, 2016). Considering these admissions, it is rather surprising that media would still call for more Western intervention, and would try to lay the rise of Islamic fundamentalism in Syria at Assad's feet.

\section{Conclusion}

The battle for Aleppo was certainly a watershed moment in the Syrian conflict and, according to virtually all international observers, has turned the tide in favour of the Syrian government. This historic dimension may well explain in part why the battle was led so ferociously by both sides and why media interest was at an all-time high, with almost daily reports in most mainstream newspapers. The available facts seem to detail the following: on the one side, a heterogeneous conglomerate of armed groups - most of which were Islamist groups with the intention of implementing Sharia law, some of which were terrorist groups with links to al-Qaeda - were fighting to retain territory that they had been occupying for roughly four and a half years by hiding amongst the civilian population, using them as human shields, and preventing them from leaving; on the other side, a government intent on retaking the city at any cost, even the large-scale killing of civilians and the indiscriminate bombing of civilian infrastructure such as schools and hospitals. The narrative, however, that was vastly embraced by the mainstream media, chose to highlight only one of the two aspects: it focused on government brutality and ruthlessness, on human rights violations due to large-scale bombing campaigns and brutal ground assaults. It did not, however, critically discuss the government's antagonists in any meaningful depth and scrutiny, and thus concealed or whitewashed their crimes.

In the media narrative, the armed groups committing human rights violations on a horrific scale and pursuing anything but a democratic transition in Syria were turned into 'moderates' whose only goal was to topple Bashar al-Assad and set up a functioning democracy with equal opportunities for all. When their violations were mentioned, this was usually done very inconspicuously, by including a short paragraph on the shelling of west Aleppo or on 'rumours' that civilians were being forcefully prevented from leaving 
east Aleppo. Such mentions are frequently placed within numerous paragraphs outlining, in great detail, the brutality of regime forces by providing what seemed like authentic sources on the ground. However, as journalist Patrick Cockburn (2017a) maintains, due to the fact that these sources had to survive in an environment controlled by armed forces known for their repression of any dissent, it is at the very least questionable that they would have been able to use the internet infrastructure without restrictions in a city bombed to rubble to transmit freely expressed and spontaneous messages. Such questions are not raised in the mainstream media narrative. Rather, eyewitness accounts are taken at face value and are thus naturalized and imbued with ultimate truth value. Any attempt to contradict or delegitimize their validity is met with immediate doubts and, in turn, delegitimized, as the following extract from The Guardian shows:

[Russian ambassador to the UN, Vitaly] Churkin said Russia shared concern for the fate of the civilian population but argued their plight would not be eased by ceasing 'counter-terrorist operations' against 'bandits' that the UK and France had 'coddled and fuelled'. He called the White Helmet civil defence organisation, which digs people out of bombed buildings, a 'pseudo-humanitarian' group, and said UN resolutions calling for an end to the bloodshed were 'a pointless tactic'. (The Guardian, 30 November 2016)

Every claim by Churkin is put in inverted commas, which serves as a distancing device while calling into question the truth value of these claims. No such distancing is used for any claims by Western countries, the rebels or Aleppo civilians, whose narratives were taken as fact, even though, based on the data available, there would have been similar grounds to doubt the validity of their statements as well.

In the case of Mosul, the set-up was reversed. The US-led coalition were 'liberators' fighting a 'ferocious' enemy. Civilian casualties were similarly high compared to Aleppo, but media coverage managed to make it appear almost as though the constant and often indiscriminate air raids by coalition forces merely accidentally occurred at the same time and place as civilian deaths (see Norton, 2017), and it was actually reported as such, e.g. 'a US airstrike that coincided with civilian deaths in Mosul' (Browne and Starr, 2017) or 'U.S.-led coalition confirms strikes hit Mosul site where civilians died' (Schmidt and Arango, 2017) or 'US reviewing airstrike that corresponds to site where 200 Iraqi civilians allegedly died' (Martinez, 2017). The causality chain that was never doubted for Aleppo and the Syrian government's fierce bombing campaign suddenly did not apply anymore and, what is more, the accused officials were given the opportunity to comment and reframe the narrative. One of the possible reasons for this difference in epistemological evaluation may lie in the difference of sources that were consulted and presupposed to be trustworthy or untrustworthy. While in Aleppo it was mostly activists or fighters with the armed opposition, in Mosul the interpretative field was yielded almost exclusively to the US-led factions doing the fighting. The claims of damage and casualties inflicted by this party were therefore automatically hedged or dismissed and, while in Aleppo, official statements by the Syrian government or its Russian allies were rightfully questioned, in Mosul no such critical inquiry took place (see Table 1).

The narrative of the 'liberation' of Mosul - that came at approximately the same human cost as the 'fall' of Aleppo - was widely embraced because the enemy, ISIS, was 
Table I. Comparative overview Aleppo vs Mosul.

\begin{tabular}{|c|c|c|}
\hline Discursive category & Aleppo & Mosul \\
\hline Use of sources & Mostly eyewitness and activists. & Mostly official sources. \\
\hline $\begin{array}{l}\text { Coverage of } \\
\text { victims }\end{array}$ & $\begin{array}{l}\text { Foregrounding civilians as } \\
\text { victims of government bombing, } \\
\text { backgrounding civilian victims of } \\
\text { armed opposition. }\end{array}$ & $\begin{array}{l}\text { Foregrounding civilians as victims } \\
\text { of ISIS and backgrounding of the } \\
\text { great number of civilian victims } \\
\text { of coalition bombings. }\end{array}$ \\
\hline $\begin{array}{l}\text { Attribution of } \\
\text { agency }\end{array}$ & $\begin{array}{l}\text { Clear chain of responsibility in the } \\
\text { case of Syrian government airstrikes. }\end{array}$ & $\begin{array}{l}\text { Hedging of responsibility of } \\
\text { US-led coalition airstrikes. }\end{array}$ \\
\hline Evaluation & $\begin{array}{l}\text { The 'fall' of Aleppo controlled by } \\
\text { Islamist forces. }\end{array}$ & $\begin{array}{l}\text { The 'liberation' of Mosul from } \\
\text { Islamist forces. }\end{array}$ \\
\hline
\end{tabular}

clearly identifiable as a brutal villain. On the other hand, the 'rebels' of Aleppo - who were primarily responsible for the news framing of the battle - had the advantage that they were initially supported by the West and their internal makeup was so complex that many reporters homogenized them into one coherent group fighting a dictator and ignored the very real and influential presence of Islamist and even terrorist elements, an admission that might have thrown some doubt on the neutrality and truth value of their reports. No one would have conceived the idea of letting ISIS frame the battle for Mosul; yet the very same privilege was awarded to al-Nusra and other al-Qaeda-affiliated groups in Aleppo.

Quite clearly, in both Aleppo and Mosul, the media chose to adopt one side of the narrative while flatly dismissing the other. As in other case studies (e.g. Boukes et al., 2015; Hannah and Cafferty, 2006; Iyengar, 1991, 1996; Kim et al., 2010; Semetko and Valkenburg, 2000), causality and responsibility frames were drawn on heavily, insinuating and often explicitly assigning blame as well as trustworthiness. In doing so, the media have arguably made a pre-judgment for their readers regarding which information is believable to begin with, not so much based on research and empirics, but along the old ideological demarcation line of us vs them, where all 'we' say is the unadulterated truth, and all 'they' say is mere propaganda to brainwash audiences into believing that black is white. Rallying behind one's leaders may be a common reflex in times of almost perpetual war, but it stands in contrast to an equally old truth that was put in rather frank terms by the investigative journalist IF Stone: 'All governments lie' (MacPherson, 2008). In particular, in times of war.

There is hence a dire need for greater scrutiny, not just of enemy sources, but also of allied sources or government sources. The important journalistic values of objectivity and balance, far too often, work out to the advantage of government agendas, having warped from a principle to a mere "defence mechanism: a "strategic ritual" that is designed to protect journalists against accusations of bias' (Freedman, 2017: 69, quoting Tuchman, 1972). This, however, frequently results in tilting the balance heavily in favour of official narratives, which are not perceived as requiring counter-balancing (Cook, 2005 [1998]: 69). It is here where the quote attributed to US Senator Hiram Johnson during World War I rings true: 'The first casualty when war comes, is truth' (Knightley, 2003 [1975]: viii). Truth, however, does not merely die on one side of the divide, but on 
both of them. The battles for Aleppo and Mosul are a grim and all-too-relevant showcase for this.

\section{Funding}

The author received no financial support for the research, authorship, and/or publication of this article.

\section{ORCID iD}

Johannes Scherling (iD https://orcid.org/0000-0002-3927-8312

\section{References}

Adriaensens D (2017) The destruction of Mosul, U.S. crimes against humanity in the name of 'counterterrorism'. Global Research, 2 October. Available at: https://www.globalresearch. ca/the-destruction-of-mosul/5611590 (accessed 4 April 2018).

Amnesty International (2015a) Torture Was My Punishment: Abductions, Torture and Summary Killings under Armed Group Rule in Aleppo and Idleb, Syria. London: Amnesty International.

Amnesty International (2015b) 'Death Everywhere': War Crimes and Human Rights Abuses in Aleppo, Syria. London: Amnesty International.

Amnesty International (2017) At Any Cost: The Civilian Catastrophe in West Mosul, Iraq. London: Amnesty International.

Anderson T (2015) War propaganda and the dirty war on Syria. Global Research, 2 December. Available at: https://www.globalresearch.ca/war-propaganda-and-the-dirty-war-on-syria /5492175 (accessed 18 January 2016).

Bagdikian BH (2004) The New Media Monopoly. Boston, MA: Beacon Press Books.

Barrington L (2016) Timeline: The battle for Aleppo. Reuters, 12 December. Available at: https:// www.reuters.com/article/us-mideast-crisis-syria-aleppo-timeline/timeline-the-battle-foraleppo-idUSKBN1430PJ (accessed 28 March 2018).

BBC (2002) Veteran CBS News anchor Dan Rather speaks out on BBC Newsnight tonight. $B B C$, 16 May. Available at: http://www.bbc.co.uk/pressoffice/pressreleases/stories/2002/05 may/16/dan_rather.shtml (accessed 16 May 2019).

BBC (2013) Guide to the Syrian Rebels. $B B C, 13$ December. Available at: https://www.bbc.com/ news/world-middle-east-24403003 (accessed 29 March 2018).

BBC (2016) Aleppo: Key dates in battle for strategic Syrian city. BBC, 13 December. Available at: https://www.bbc.com/news/world-middle-east-38294488 (accessed 29 March 2018).

BBC (2018) Jumpei Yasuda: Japanese journalist held in Syria is safe. $B B C, 24$ October. Available at: https://www.bbc.com/news/world-middle-east-45954637 (accessed 16 May 2019).

Bertrand N (2016a) The Defense Department has a new line that helps Putin and Assad in Syria. Business Insider, 25 April. Available at: https://www.businessinsider.de/defense-departmentnusra-aleppo-putin-assad-2016-4? $\mathrm{r}=\mathrm{US} \& I R=\mathrm{T}$ (accessed 7 September 2017).

Bertrand N (2016b) McCain and Graham issue blistering statement on Aleppo, Syria. Business Insider, 13 December. Available at: https:/www.businessinsider.de/mccain-and-grahamissue-blistering-statement-on-aleppo-syria-2016-12? $\mathrm{r}=\mathrm{US} \& \mathrm{IR}=\mathrm{T}$ (accessed $29 \mathrm{March}$ 2018).

Boukes M et al. (2015) Political news with a personal touch: How human interest framing indirectly affects policy attitudes. Journalism \& Mass Communication Quarterly 92(1): 121-141. 
Browne R and Starr B (2017) Investigation of Mosul civil casualties expanded. CNN, 31 March. Available at: https:/edition.cnn.com/2017/03/30/politics/mosul-airstrike-formal-investigation/index.html (accessed 24 July 2018).

Callimachi R, Kirkpatrick DD and Pérez-Peña R (2019) John Cantlie, a British journalist held hostage by ISIS, is believed to be still alive. The New York Times, 5 February. Available at: https://www.nytimes.com/2019/02/05/world/middleeast/john-cantlie-alive-isis.html (accessed 16 May 2019).

Chomsky N and Herman ES (2002[1988]) Manufacturing Consent: The Political Economy of the Mass Media, 2nd edn. New York: Pantheon Books.

Cockburn P (2010) Embedded journalism: A distorted view of war. The Independent, 23 November. Available at: https://www.independent.co.uk/news/media/opinion/embedded-journalism-adistorted-view-of-war-2141072.html (accessed 16 May 2019).

Cockburn P (2017a) Who supplies the news? London Review of Books 39(3): 7-9.

Cockburn P (2017b) The massacre of Mosul: 40,000 feared dead in battle to take back city from Isis as scale of civilian casualties revealed. The Independent, 19 July. Available at: https:// www.independent.co.uk/news/world/middle-east/mosul-massacre-battle-isis-iraq-city-civilian-casualties-killed-deaths-fighting-forces-islamic-state-a 7848781.html (accessed $28 \mathrm{March}$ 2018).

Cook TE (1998/2005) Governing with the News: The News Media as a Political Institution, 2nd edn. Chicago: University of Chicago Press.

Cromwell D and Edwards D (2017) Mass media siege: Comparing coverage of Mosul and Aleppo. Media Lens, 18 July. Available at: http://www.medialens.org/index.php/alerts/ alert-archive/2017/852-mass-media-siege-comparing-coverage-of-mosul-and-aleppo.html (accessed 9 April 2017).

Cru JN (1988) War Books: A Study in Historical Criticism. San Diego, CA: San Diego University Press.

De Vreese CH (2005) News framing: Theory and typology. Information Design Journal + Document Design 13(1): 51-62.

De Vreese CH (2009) News framing and public support for a common foreign and security policy. Journal of Common Market Studies 47(3): 453-481.

Dearden L (2016) Former US military adviser David Kilcullen says there would be no Isis without Iraq invasion. The Independent, 4 March. Available at: https:/www.independent.co.uk/ news/world/middle-east/iraq-war-invasion-caused-isis-islamic-state-daesh-saysus-militaryadviser-david-kilcullen-a6912236.html (accessed 27 July 2018).

Department of Defense (2017) Department of Defense briefing by Gen. Townsend via telephone from Baghdad, Iraq. Department of Defense, 28 March. Available at: https://dod.defense. gov/News/Transcripts/Transcript-View/Article/1133033/department-of-defense-briefing-bygen-townsend-via-telephone-from-baghdad-iraq/ (accessed 29 March 2018).

Entman RB (1993) Framing: Toward clarification of a fractured paradigm. Journal of Communication 43: 51-58.

Entman RB (2004) Projections of Power: Framing News, Public Opinion, and U.S. Foreign Policy. Chicago: University of Chicago Press.

Eshchenko A and Sterling J (2016) 'Are you truly incapable of shame?' Samantha Power blasts Assad regime, allies. CNN, 14 December. Available at: https://edition.cnn.com/2016/12/14/ middleeast/aleppo-samantha-power-speech/index.html (accessed 29 March 2018).

Freedman D (2017) Critical perspectives on media and conflict. In: Robinson P et al. (eds) Routledge Handbook of Media, Conflict and Security. New York: Routledge, 68-79.

Garamone J (2016) Iraqi offensive to liberate Mosul entering critical phase. DoD News, 11 November. Available at: http://www.centcom.mil/MEDIA/NEWS-ARTICLES/News- 
Article-View/Article/1002585/iraqi-offensive-to-liberate-mosul-entering-critical-phase/ (accessed 29 March 2018).

Geneva International Centre for Justice (2017) Mosul: Destruction and accountability. Available at: http://www.gicj.org/un-special-procedures-appeals/iraq/1156-mosul-destruction-andaccountability (accessed 29 March 2018).

Gitlin T (1980) The Whole World Is Watching. Berkeley: University of California Press.

Goatly A (2000) Critical Reading and Writing. New York: Routledge.

GOV.UK (2016) Joint statement on Aleppo: 7 December. Gov.uk, 7 December. Available at: https://www.gov.uk/government/news/joint-statement-on-aleppo-7-december-2016 (accessed 28 March 2018).

The Guardian (2019) German journalist who gave birth as hostage in Syria speaks of ordeal. The Guardian, 21 March. Available at: https:/www.theguardian.com/world/2019/mar/21/ german-journalist-who-was-held-captive-and-gave-birth-in-syria-speaks-of-her-ordeal (accessed 16 May 2019).

Hannah G and Cafferty TP (2006) Attribute and responsibility framing effects in television news coverage of poverty. Journal of Applied Social Psychology 36(12): 2993-3014.

Hauch L (2016) Sharia law will play a greater role in Syria's future. Middle East Eye, 9 June. Available at: https://www.middleeasteye.net/columns/no-need-run-if-you-hearsharia-101217981 (accessed 20 July 2018).

Hersh S (2018) Reporter: A Memoir. New York: Alfred A Knopf.

Human Rights Watch (2018) World Report 2018: Iraq. Human Rights Watch. Available at: https:// www.hrw.org/world-report/2018/country-chapters/iraq (accessed 6 April 2018).

Irish J (2016) U.N. Syria envoy says rebel city Idlib risks Aleppo fate if no peace talks. Reuters, 16 December. Available at: http://www.reuters.com (accessed 6 June 2018).

Iyengar S (1991) Is Anyone Responsible? How Television Frames Political Issues. Chicago: University of Chicago Press.

Iyengar S (1996) Framing responsibility for political issues. Annals of the American Academy of Political and Social Science 546: 59-70.

Jones H(2018) The lessons of My Lai still resonate. The Washington Post, 16 March. Available at:https:// www.washingtonpost.com/opinions/the-lessons-of-my-lai-still-resonate/2018/03/15/4d35613a2708-11e8-874b-d517e912f125_story.html?noredirect=on\&utm_term=.1281fdb959b9 (accessed 27 July 2018).

Kim SH, Carvalho JP and Davis AG (2010). Talking about poverty: News framing of who is responsible for causing and fixing the problem. Journalism and Mass Communication Quarterly 87(3/4): 563-581.

Kinzer S (2016) The media are misleading the public on Syria. Boston Globe, 18 February. Available at: https://www.commondreams.org/views/2016/02/22/media-are-misleadingpublic-syria (accessed 24 February 2016).

Knightley P (2003[1975]) The First Casualty: The War Correspondent as Hero, Propagandist and Myth-Maker from the Crimea to Iraq. London: André Deutsch.

Lippmann W (2012[1920]) Liberty and the News. Classic Reprint Series, Forgotten Books.

MacFarquhar N (2013) A very busy man behind the Syrian Civil War's casualty count. The New York Times, 9 April. Available at: https:/www.nytimes.com/2013/04/10/world/middleeast/ the-man-behind-the-casualty-figures-in-syria.html (accessed 27 July 2018).

MacLeod A (2018) Bad News from Venezuela: Twenty Years of Fake News and Misreporting. New York: Routledge.

MacPherson M (2008) 'All Governments Lie': The Life and Times of Rebel Journalist I.F. Stone. New York: Scribner. 
Martinez L (2017) US reviewing airstrike that corresponds to site where 200 Iraqi civilians allegedly died. $A B C$ News, 25 March. Available at: https://abcnews.go.com/International/usreviewing-airstrikes-iraq-syria-killed-100s-civilians/story?id=46361783 (accessed 31 March 2017).

Murray S (2017) The 'rally-'round-the-flag' phenomenon and the diversionary use of force. Oxford Research Encyclopedia of Politics. Available at: https://oxfordre.com/politics/view/10.1093/ acrefore/9780190228637.001.0001/acrefore-9780190228637-e-518 (accessed 17 May 2019).

New York Post (2016) Deal reached to complete Aleppo evacuations, 17 December. Available at: https://nypost.com/2016/12/17/deal-reached-to-complete-aleppo-evacuations/ (accessed 26 July 2018).

Norton B (2017) Media spin headlines to downplay US responsibility for Mosul massacre. FAIR, 30 March. Available at: https://fair.org/home/media-spin-headlines-to-downplay-us-responsibility-for-mosul-massacre/ (accessed 31 March 2018).

Oborne P (2016) Journey to Aleppo: How the war ripped Syria's biggest city apart. Middle East Eye, 10 February. Available at: https://www.middleeasteye.net/essays/journey-aleppo-howwar-ripped-syrias-biggest-city-apart-1376989223 (accessed 16 February 2016).

OHCHR (2016) Statement by the Independent International Commission of Inquiry on the Syrian Arab Republic on the situation of civilians affected by the capture of Aleppo, 14 December. Available at: https://www.ohchr.org/RU/HRBodies/HRC/Pages/NewsDetail. aspx?NewsID=21031\&LangID=R (accessed 6 September 2017).

OHCHR (2017a) Press briefing notes on Mosul \& Kyrgyzstan, 24 January. Available at: https:// www.ohchr.org/FR/NewsEvents/Pages/DisplayNews.aspx?NewsID=21112\&LangID=E (accessed 29 March 2018).

OHCHR (2017b) Report of the Independent International Commission of Inquiry on the Syrian Arab Republic, 2 February. Available at: https://www.ohchr.org/en/hrbodies/hrc/iicisyria/ pages/independentinternationalcommission.aspx (accessed 29 March 2018).

Philo G (2004) The mass production of ignorance: News content and audience. In: Paterson CA and Sreberny A (eds) International News in the 21st Century. Eastleigh: Libbey, 199-224.

Philo G (2008) Can discourse analysis successfully explain the content of media and journalistic practice? Journalism Studies 8(2): 175-196.

Philo G and Berry M (2004 [2011]) More Bad News from Israel. London: Pluto Press.

Philo G, Briant E and Donald P (2013) Bad News for Refugees. London: Pluto Press.

Rodgers L, Stylianou Nand Dunford D (2017) Is anything left of Mosul? BBC, 9 August. Available at: https://www.bbc.co.uk/news/resources/idt-9d41ef6c-97c9-4953-ba43-284cc62ffdd0 (accessed 29 March 2018).

RSF (2018) RSF calls for the UN to appoint a Special Representative for the Safety of Journalists. Available at: https://rsf.org/en/news/rsf-calls-un-appoint-special-representative-safety-journalists (accessed 16 May 2019).

RT (2016a) Thousands of civilians trapped inside rebel-held parts of Aleppo as fighting intensifies, 2 December. Available at: https://www.rt.com/news/368939-aleppo-civilians-trappedmilitants/ (accessed 28 March 2018).

RT (2016b) Lavrov: Kerry finally presented proposals on Aleppo in line with Russia's stance. RT, 3 December. Available at: https://www.rt.com/news/369093-us-aleppo-russia-talks/ (accessed 28 March 2018).

RT (2016c) Liberation of E. Aleppo from militants complete - Russian military, 16 December. Available at: https://www.rt.com/news/370510-aleppo-women-children-evacuated/ (accessed 27 July 2018). 
Sabbagh H (2016) Terrorists in Aleppo's eastern neighborhoods monopolizing food and preventing civilians from leaving. SANA, 27 November. Available at: https://sana.sy/en/?p=94445 (accessed 28 March 2018).

Schmidt MS and Arango T (2017) U.S.-led coalition confirms strikes hit Mosul site where civilians died. New York Times, 25 March. Available at: https://www.nytimes.com/2017/03/25/us/ politics/us-led-coalition-confirms-strikes-hit-mosul-site-where-civilians-died.html (accessed 31 March 2018).

Semetko HA and Valkenburg PM (2000) Framing European politics: A content analysis of press and television news. Journal of Communications, Spring: 93-109.

Shaheen K (2016) Battles rage across Aleppo as Assad regime fights to quell rebels. The Guardian, 8 August. Available at: https://www.theguardian.com/world/2016/aug/08/battles-rageacross-aleppo-as-assad-regime-syria-fights-to-quash-rebels (accessed 4 April 2018).

Shapira I (2018) 'It was insanity': At My Lai, U.S. soldiers slaughtered hundreds of Vietnamese women and kids. The Washington Post, 16 March. Available at: https://www.washingtonpost. com/news/retropolis/wp/2018/03/16/it-was-insanity-at-my-lai-u-s-soldiers-slaughtered-hundreds-of-vietnamese-women-and-kids/?utm_term=.928db6ca42d1 (accessed 27 July 2018).

Sky News (nd) The Battle for Mosul: How fight for the city unfolded. Sky News. Available at: https:// news.sky.com/story/the-battle-for-mosul-how-the-recapture-of-the-city-unfolded-10809440 (accessed 25 July 2018).

Sly L and Ignatius D (2013) Islamic law comes to rebel-held areas of Syria. The Washington Post, 19 March. Available at: https://www.washingtonpost.com/world/middle_east/islamiclaw-comes-to-rebel-held-syria/2013/03/19/b310532e-90af-11e2-bdea-e32ad90da239_story. html?utm_term=.c7cbbadd82b8 (accessed 20 July 2018).

Talbot M (1992) The construction of gender in a teenage magazine. In: Fairclough N (ed.) Critical Language Awareness. Harlow: Longman, 174-199.

Tuchman G (1972) Objectivity as strategic ritual. American Journal of Sociology 77(4): 660-679.

UN HABITAT (2017) Multi-sector damage assessment, 8 July. Available at: http://unhabitatiraq. net/mosulportal/wp-content/uploads/2017/07/170713_Damage-Assessment.pdf (accessed 29 March 2018).

UNESCO (2017) UNESCO reports on extensive damage in first emergency assessment mission to Aleppo. UNESCO, 19 January. Available at: https:/en.unesco.org/news/unesco-reportsextensive-damage-first-emergency-assessment-mission-aleppo (accessed 6 April 2018).

UNHCR (2017) As 1000s flee West Mosul, UNHCR opens 12th new camp for displaced, 12 May. Available at: https://www.unhcr.org/news/briefing/2017/5/591579e74/1000s-flee-westmosul-unhcr-opens-12th-new-camp-displaced.html (accessed 6 April 2018).

UNITAR (2016) Damage density in the City of Aleppo, Syria, 15 December. Available at: http:// www.unitar.org/unosat/map/2508 (accessed 31 March 2018).

Violations Documentation Center in Syria (nd) Killed list. Available at: http://www.vdc-sy.info/ index.php/en/martyrs (accessed 27 July 2018).

Walker P (2016) Theresa May joins condemnation of Russia over Aleppo bombings. The Guardian, 7 December. Available at: https://www.theguardian.com/world/2016/dec/07/theresa-maycondemnation-russia-aleppo-bombings-syria (accessed March 28, 2018).

Weiss P (2017) US watched ISIS rise in Syria and hoped to 'manage' it - Kerry on leaked tape. Mondoweiss, 11 January. Available at: https://mondoweiss.net/2017/01/watched-manageleaked/ (accessed 29 March 2018).

The White House (2016a) Press briefing by Press Secretary Josh Earnest, 12 September. Available at: https://obamawhitehouse.archives.gov/the-press-office/2016/09/12/press-briefing-presssecretary-josh-earnest-9122016 (accessed 28 March 2018). 
The White House (2016b) Press conference of President Obama and Prime Minister Renzi of the Republic of Italy, 18 October. Available at: https://obamawhitehouse.archives.gov/the-pressoffice/2016/10/18/press-conference-president-obama-and-prime-minister-renzi-republicitaly (accessed 29 March 2018).

The White House (2016c) Press briefing by Press Secretary Josh Earnest, 7 December. Available at: https://obamawhitehouse.archives.gov/the-press-office/2016/12/07/press-briefing-presssecretary-josh-earnest-1272016 (accessed 28 March 2018).

\section{Author biography}

Johannes Scherling is a lecturer of English Linguistics and British Cultural Studies at the KarlFranzens-University in Graz, Austria. His main research areas are the pragmatics of English loanwords in the Japanese language as well as critical media analysis of foreign policy events, with a particular focus on the news framing, the omission and backgrounding of alternative narratives and cause-effect perception. His latest publications include articles such as Focalizing Memory Synchronicity and Historicity in the Discourse on the Charlie Hebdo Attack in UK Media (2015), "Trust, but Verify" - The Framing of the Nuclear Conflict between Iran and the West in UK and US media (2016), and Frames, cognition, ideology. And Chomsky (2018) as well as the monograph Japanizing English - Anglicisms and their impact on Japanese (2012). The corpus used for the analysis is available upon email request to the author. 